\title{
Produção do anti-soro e detecção por DAS-Elisa do Melon yellowing-associated virus em meloeiro
}

\author{
Antonio C. Ávila ${ }^{1}$, Alice K. Inoue-Nagata ${ }^{1}$, Filipe M. Neves², Luciana G. Matos², Rita de Cássia S. Dias ${ }^{3}$, \\ Maurício Rangel $^{4}$ \& Tatsuya Nagata ${ }^{2}$
}

${ }^{1}$ Embrapa Hortaliças, Cx. Postal 218, 70359-970, Brasília, DF, Brasil; ${ }^{2}$ Graduação e Pós-Graduação em Ciências Genômicas e Biotecnologia, Universidade Católica de Brasília, 70790-160, Brasília, DF, Brasil; ${ }^{3}$ Embrapa Semi-Árido, Cx. Postal 23, 56302-970 Petrolina, PE, Brasil; ${ }^{4}$ Syngenta Seeds Ltda, Cx. Postal 71, 62800-000, Aracati, CE, Brasil

Autor para correspondência: Antonio C. Ávila, e-mail: avila@cnph.embrapa.br

\begin{abstract}
RESUMO
A doença conhecida como "Amarelão do Meloeiro" é hoje uma das principais doenças em meloeiro no Nordeste do Brasil. Até o momento, somente o Melon yellowing-associated virus (MYaV), transmitido por moscas-brancas, foi detectado em plantas doentes e constitui-se no provável agente causador da doença. Para permitir uma diagnose inequívoca da doença, este trabalho objetivou a produção e avaliação de anti-soro policlonal contra o isolado "Bessa" de MYaV. Partículas virais foram purificadas e injetadas em coelhos para a produção do anti-soro, que mostrou ser específico sem a ocorrência de reações com extrato de plantas sadias e outros vírus que infectam o melão. Para a avaliação do anti-soro, 14 amostras de meloeiro com sintomas de amarelão oriundas de campos de produção de Pernambuco e Rio Grande do Norte foram avaliadas em DAS-Elisa. Onze amostras reagiram positivamente e verificou-se que a concentração viral maior é vista na haste e não nas folhas, sendo o tecido a ser selecionado para a realização de testes de detecção. Esse estudo demonstrou que o antisoro policlonal produzido contra o MYaV é específico e poderá ser utilizado na detecção desse vírus em plantios comerciais de melão.
\end{abstract}

Palavras chave: amarelão, MYaV, carlavírus, flexivírus, detecção, sorologia.

\begin{abstract}
Antiserum production and detection by DAS-Elisa of Melon yellowing-associated virus on melon plants

Today, the disease known as "Melon yellowing" is one of the major melon diseases in melon growing areas in the Northeast of Brazil. Up to the moment, only the Melon yellowing-associated virus (MYaV), transmitted by whiteflies, was detected in diseased plants, and it is the probable causing agent of the disease. To enable the unequivocal diagnosis of the disease, this study aimed to produce and evaluate a polyclonal antibody against the "Bessa" isolate of MYaV. Viral particles were purified and injected into rabbits for antiserum production, which was specific without any reaction with healthy plant sap. For antiserum evaluation, 14 melon samples with yellowing symptom from fields of Pernambuco and Rio Grande do Norte were evaluated by DAS-Elisa. A total of eleven samples reacted positively and the test showed that the virus concentration is higher at the stems instead of leaves, and therefore stems should be selected to be used in detection tests. This study demonstrated that the polyclonal antiserum produced against MYaV was specific and can be used to detect it in commercial melon fields.
\end{abstract}

Keywords: yellowing, MYaV, carlavirus, flexivirus, detection, serology.

A produção de melão no Brasil é concentrada principalmente nos Estados do Rio Grande do Norte, Ceará, Pernambuco e Bahia e na região do Submédio São Francisco. No ano de 2006, o Brasil produziu 500 mil toneladas de melão em 21.000 ha (IBGE, 2007) destinadas ao consumo interno e exportação. O meloeiro é suscetível a vários vírus sendo o principal o Papaya ringspot virus (PRSV), família Potyviridae, gênero Potyvirus (Zambolin et al., 2000). A partir do ano de 2002, com o aumento da incidência da mosca-branca Bemisia tabaci biótipo $\mathrm{B}$ nas áreas de produção de melão, observou-se o surgimento de sintomas de clorose generalizada nas folhas baixeiras do meloeiro e clareamento de nervuras, pontos cloróticos e mosaico nas folhas intermediárias. Não há aparentemente redução de tamanho e número de frutos, mas queda acentuada do "brix" tem sido observada. Como as plantas apresentavam uma coloração generalizada de um amarelo intenso, os produtores denominaram a doença de "Amarelão do Meloeiro". Em plantas infectadas e analisadas em microscópio eletrônico foram observadas consistentemente partículas flexuosas e inclusões semelhantes àquelas induzidas por espécies do gênero Carlavirus, família Flexiviridae (Nagata et al., 2003). A análise do genoma parcial viral mostrou que muito possivelmente trata-se de uma nova espécie de vírus relacionada com os carlavírus da família Flexiviridae, tentativamente nomeado de Melon yellowing-associated 
virus (MYaV) (Nagata et al., 2005). Outra característica desse vírus é a sua não transmissão mecânica, mas somente através de mosca-branca e enxertia (Nagata et al., 2003). Um isolado do MYaV denominado "Bessa", originário do Estado do Ceará, foi multiplicado através de enxertia em plantas de maxixe e purificado utilizando o método descrito por Naidu et al. (1998). Resumidamente, este consistiu em triturar folhas infectadas de maxixe com tampão (10 $\mathrm{mM}$ fosfato, $\mathrm{pH} 8,0,10 \mathrm{mM}$ DIECA e $2 \%$ tioglicerol) e centrifugar a baixa rotação para remoção dos resíduos celulares. Ao sobrenadante adicionou-se $0,2 \mathrm{M}$ de $\mathrm{Na}_{2} \mathrm{PO}_{4}$ e $1,0 \mathrm{M}$ de $\mathrm{CaCl}_{2}$ deixando-se sob agitação lenta por 20 min a $6^{\circ} \mathrm{C}$. Após centrifugação a baixa rotação, adicionou-se polietileno glicol 6000 e manteve-se sob agitação por 1h. Em seguida, após baixa centrifugação, ressuspendeu-se o sedimento com tampão fosfato (100 mM fosfato, $200 \mathrm{mM}$ uréia, $\mathrm{pH}$ 8,3 , com $0,1 \%$ Triton X-100) e sedimentou-se as partículas com dois ciclos de ultracentrifugação em almofada de sacarose, de 20 e $30 \%$, respectivamente. Após centrifugação em gradiente de sacarose (10 a 40\%) uma banda opaca foi coletada. $\mathrm{O}$ vírus foi concentrado por ultracentrifugação, obtendo-se um rendimento de $228 \mu \mathrm{g}$ de vírus por $100 \mathrm{~g}$ de folha. Três injeções subcutâneas com partículas purificadas emulsificadas com adjuvante incompleto de Freund's foram realizadas em coelho para obtenção de anti-soro policlonal. $\mathrm{O}$ anti-soro bruto foi avaliado em teste Elisa indireto para a avaliação da reatividade e especificidade. Avaliaram-se três diluições do anti-soro bruto $(1: 500 ; 1: 1000 ; 1: 2000)$ e duas diluições do extrato de planta infectada $(1: 10 ; 1: 100)$. Nas três diluições do anti-soro, foi verificada uma clara distinção entre o extrato de planta sadia e extrato de planta infectada (Figura 1), demonstrando a especificidade do anti-soro.
Houve diferença na reação nas diluições do extrato de planta somente nas concentrações mais baixas do anti-soro. O antisoro foi utilizado para a purificação da imunoglobulina, para a produção do conjugado com a enzima fosfatase alcalina e nos testes de detecção por DAS-Elisa (Clark \& Adams, 1977) na concentração de $\mathrm{IgG}$ de $1 \mathrm{mg} / \mathrm{ml}$. A análise de 14 amostras de melão com sintomas de amarelão oriundas de campos de produção nos Estados de Pernambuco e do Rio Grande do Norte (Figura 2) mostrou que o anti-soro reagiu de forma específica com o MYaV, confirmando a presença do vírus nos dois estados brasileiros. Do total de cinco amostras de meloeiro coletadas em Pernambuco, o MYaV foi detectado em quatro (Figura 2, amostras 1-5). Das nove amostras provenientes do estado de Rio Grande do Norte, sete reagiram positivamente (Figura 2, amostras 6-14). A detecção negativa nas amostras com sintomas provavelmente foi devido à baixa concentração do vírus. $\mathrm{O}$ vírus foi claramente detectado nas hastes de meloeiro, mas não em folhas da mesma planta, sejam elas velhas ou jovens, com ou sem sintomas (Figura 2). Portanto, em condições de campo, faz-se necessário testar a presença do vírus nas hastes ao invés das folhas. O ensaio para avaliar a ocorrência de reação cruzada demonstrou que o anti-soro contra o MYaV não apresenta reação com outros vírus de cucurbitáceas como o PRSV, Zucchini yellow mosaic virus (ZYMV), Watermelon mosaic virus (WMV) e Cucumber mosaic virus (CMV). Esse estudo demonstrou que o anti-soro policlonal produzido contra o MYaV é específico e poderá ser utilizado na detecção desse vírus a partir de plantas em plantios comerciais de melão. Até o presente, nenhum método de detecção de MYaV estava disponível para diagnose.

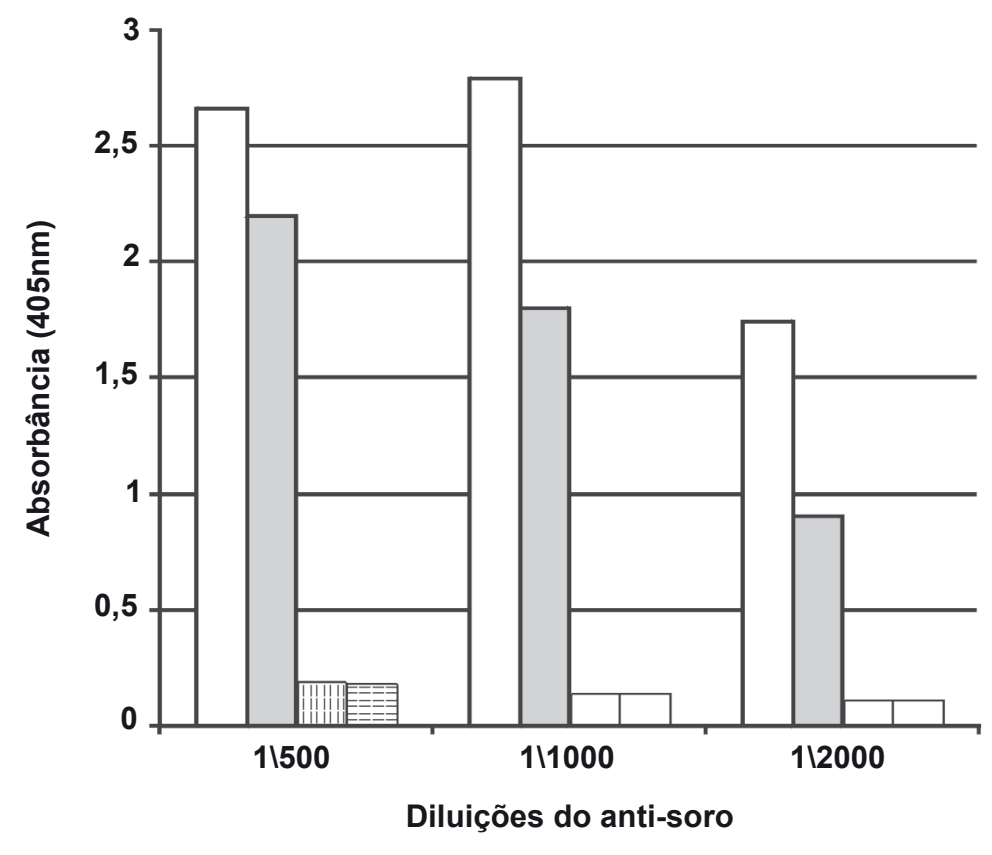

FIG. 1 - Avaliação do anti-soro para o MYaV utilizando extrato de plantas de melão sadio e infectado. Anti-soro diluído em 1:500, 1:1000 e 1:2000. Coluna branca $=$ folha infectada na diluição $1: 10$, coluna cinza $=$ folha infecta na diluição 1:100; coluna com linha vertical = folha sadia na diluição 1:10 e coluna com linha horizontal $=$ folha sadia na diluição 1:100.

Tropical Plant Pathology 33 (3) May - June 2008 


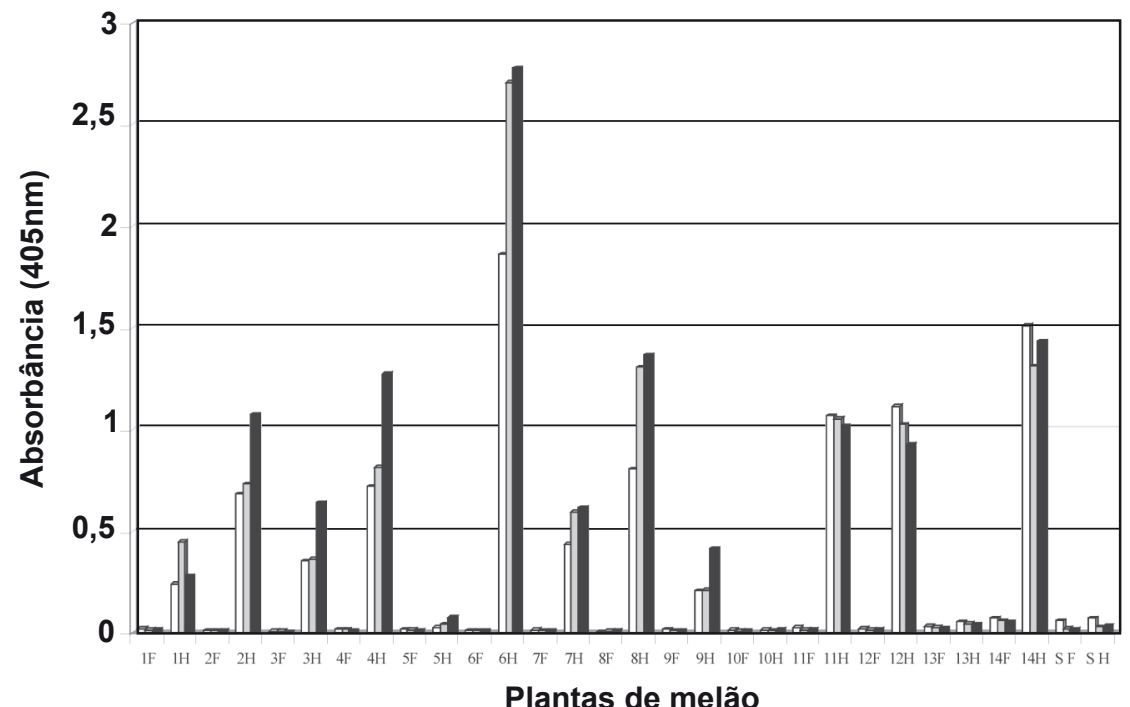

FIG. 2 - Detecção do MYaV utilizando anti-soro policlonal e plantas de meloeiro naturalmente infectadas no campo. Amostras 1 a 5 provenientes do estado de Pernambuco, amostras 6 a 14 do estado do Rio Grande do Norte. Coluna branca $=$ diluição $1: 10$, coluna cinza $=$ diluição $1: 100$, coluna preta $=$ diluição $1: 1000 ; \mathrm{F}$ $=$ folha; $\mathrm{H}=$ haste; $\mathrm{SF}=$ controle sadio de folha, e $\mathrm{SH}=$ controle sadio de haste.

\section{AGRADECIMENTOS}

Pesquisa financiada pelo Conselho Nacional de Desenvolvimento Cientifico e Tecnológico - CNPq. Agradecemos ao técnico Lúcio Flávio Barbosa por sua assistência na condução dos experimentos.

\section{REFERÊNCIAS BIBLIOGRÁFICAS}

Clark MF, Adams AN (1977) Characteristics of the microplate method of enzyme linked immunosorbent assay for the detection of plant viruses. Journal of General Virology 34:475-483.

IBGE. Produção Agrícola Municipal 2007. Lavoura temporária melão. Produção e área plantada de melão, Brasil, 2006. Rio de Janeiro (IBGE). Disponível em www.sidra.ibge.gov.br. Acesso em 20/02/2008.

Nagata T, Kitajima EW, Alves DM, Cardoso JE, Inoue-Nagata AK, Oliveira MRV, de Ávila AC (2003) Isolation of a novel carlavirus from melon in Brazil. Plant Pathology 52:797. (Disease Note)

Nagata T, Alves DMT, Inoue-Nagata AK, Tian TY, Kitajima EW, Cardoso JE, de Ávila AC (2005) A novel flexivirus transmitted by whitefly. Archives of Virology 150:379-387.

Naidu RE, Gowda S, Satyanaraayana T, Boyko V, Reddy AS, Dawson WO, Reddy DVR (1998) Evidence that whiteflytransmitted cowpea mild mottle virus belongs to the genus Carlavirus. Archives of Virology 143:769-780.

Zambolim L, Vale F.X.R, Costa H (2000) Vírus da mancha anelar do mamoeiro: estirpe melancia. In: Zambolim L, Vale FXR, Costa $\mathrm{H}$ (Eds.) Controle de doenças de plantas: hortaliças. Viçosa MG. Universidade Federal de Viçosa. v. 2. pp. 600-601. 